\title{
鉄筋コンクリート造建築物における \\ 部材測定面毎のかぶり厚さ平均值の分布に関する分析 \\ DISTRIBUTION OF AVERAGE THICKNESS OF COVER CONCRETE \\ ON EACH MEASURING FACE OF ANY MEMBER \\ IN REINFORCED CONCRETE STRUCTURES
}

\author{
西村 進 ${ }^{* 1}$, 桝田佳寛*2, 松 崎育弘*3, 園部 泰 寿*4 \\ Susumu NISHIMURA, Yoshihiro MASUDA, Yasuhiro MATSUZAKI \\ and Yasuhisa SONOBE
}

\begin{abstract}
When the average thickness of additional cover concrete in design phase and that in construction phase are separately analyzed for each type of member such as column, beam, etc., it showed an almost normal distribution, respectively. Furthermore, concerning the relationship between distribution of the average cover concrete thickness on each measuring face of any member and the deviation within a member, a tendency was found that the deviation within a member increases along with an increase in the average value while the former remains small as far as the latter is small.
\end{abstract}

Keywords : Thickness of cover concrete, average value of measuring face, Distribution, Fluctuation, Deviation within a member, かぶり厚さ，測定面の平均值，分布，ばらつき，部材内偏差

\section{1. はじめに}

鉄筋コンクリート造建築物において、鉄筋のかぶり厚さがどの程 度確保されているかは、構造体の耐久性に関わる重要な要素である。 しかしながら、実際の建築工事では施工の良否ばかりではなく鉄筋 の加工・組立て等施工上の誤差が原因でかぶり厚さがばらくため、 設計かぶり厚さ－10mm の最小かぶり厚さを満足することは容易な ことではない。このような状沉にも拘わらず、実際の建築物におけ るかぶり厚さの実態に関する調査や研究報告 ${ }^{1), 2}$ は少なく、かぶり 厚さの分布やばらつきに関する十分な知見が得られていない。

既報 $\left.{ }^{3)}, 4\right), 5$ ) では、竣工後の建物 18 棟について、柱の帯筋 (以下、 柱という)、耐力壁の横筋 (以下、壁という) 、大梁あばら筋の側面 (以 下、梁側面という)、大梁あばら筋の下面(以下、梁下面という) およ びスラブの下端主筋 (以下、スラブ下面という)を対象とした非破壊 試験によるかぶり厚さ調查結果をもとに、かぶり厚さの分布やばら つきに関する分析結果を報告した。既報 $1^{3)}$ では、鉄筋 1 本毎のかぶ り厚さについて部材種別毎、建物毎の分布と標準偏差を、また一部 材の一測定面でのかぶり厚さのばらつき (以下、部材内偏差という) や複数の部材間でのかぶり厚さのばらつき(以下、部材間偏差とい う）等について報告を行った。既報 $2^{4}$ およよび既報 $3^{5)}$ では、かぶり厚 さの分布に及ぼす割増し ${ }^{\text {i } 1)}$ や打増し注 ${ }^{1)}$ の影響と施工方法の影響に ついて報告した。これらの分析結果から、部材内偏差は全体的に小 さいものの部材間偏差が比較的大きく、これによって鉄筋 1 本毎
のかぶり厚さの標準偏差が大きくなる傾向があることが分かってい る。このことは、かぶり厚さの小さい箇所は建物全体に分散してい るのではなく、ある部材のかぶり厚さが全体的に小さいという傾向 があることを示唆している。本報告では、部材測定面毎のかぶり厚 さの平均值の分布と、部材測定面毎のかぶり厚さの平均值と部材内 偏差の関係について分析を行った。

\section{2. 建物の概要}

対象とした建物は、既報 ${ }^{3), 4), 5)}$ と同様で 2003 年から 2006 年の間 首都圈に建設された一般的な形状をした集合住宅 18 棟である。設計 図書および竣工図によると、各建物とも現場打ちの鉄筋コンクリー ト造であり、鉄筋コンクリート工事に関する仕様は JASS5 1997 年版 に準拠している。各建物の規模および部材種別毎の調查部材面数を 表 1 に示す。かぶり厚さは、柱、梁および耐力壁の屋外側が最小か ぶり厚さ $40 \mathrm{~mm}$, 設計かぶり厚さ $50 \mathrm{~mm}$ 、屋内側は最小かぶり厚さ $30 \mathrm{~mm}$, 設計かぶり厚さ $40 \mathrm{~mm} 、$ スラブの屋外側が最小かぶり厚さ $30 \mathrm{~mm}$, 設計 かぶり厚さ $40 \mathrm{~mm}$ となっている。調查建物 18 棟は同一の建設会社に よって建築工事が行われており、鉄筋の組立て工法は建物番号 9, 11，12 の大梁において鉄筋先組み工法が採用されている他は、現地 で鉄筋を組立てる在来工法となっている。鉄筋の加工は、スパイラ ル筋および溶接閉鎖型せん断補強筋がメーカーで製作され、その他 の鉄筋は鉄筋工事専門会社の加工工場で行われている。また、鉄筋

\footnotetext{
*1 宇都宮大学大学院工学研究科 博士後期課程

*2 宇都宮大学工学研究科地球環境デザイン学専攻 教授・工博

*3 東京理科大学 名誉教授. 工博

$* 4$ 筑波大学 名誉教授. 工博
}

Graduate School of Engineering, Utsunomiya University

Prof., Dept. of Design and Engineering for Global Environment, Architecture Course,

Utsunomiya University, Dr. Eng.

Prof. Emeritus, Tokyo University of Science, Dr. Eng.

Prof. Emeritus, University of Tsukuba, Dr. Eng. 
の組立て作業は、建物毎に一班の鉄筋工事施工班が担当している。 かぶり厚さに関わる帯筋、あばら筋の加工組立用の寸法は、設計 断面に対して屋外屋内側ともにかぶり厚さ $50 \mathrm{~mm}$ とし、あばら筋では 梁と交差する柱主筋径等を考慮した割増しを加えて計画かぶり厚さ としている。また、スペーサの仕様は各建物とも同様で、柱，壁， 梁側面にはプラスチック製ドーナツ型スペーサ、梁下面にはコンク リートブロック製スペーサ、スラブには足元が防錆塗装された鋼製 スペーサまたはプラスチック製スペーサが使用されている。

\section{3. 調査の概要}

かぶり厚さの調査は、調査建物 18 棟の主に偶数階を対象として行 い、開放廊下等共用部から調查可能な範囲について、非破壞試験に よる測定を行った。かぶり厚さ測定方法は既報 ${ }^{3)}$ の通りであり、柱 壁、梁側面および梁下面は測定面のほぼ中央の 1 探查線上を、また スラブ下面は大梁側面からほぼ $50 \mathrm{~cm}$ 離れた 1 探查線上を探査器で 連続的に測定した。非破壊試験は電磁誘導法による鉄筋探査システ ム FS-10 (H 社製)を使用し、取得したデータを専用のソフトウェアで デジタルデータ化し、型枠セパレータ等明らかに鉄筋のかぶり厚さ ではないと判断されるものを削除してかぶり厚さ測定值とした。

電磁誘導法による非破壊探查機器を使用して鉄筋のかぶり厚さ測 定を行う場合、かぶり厚さが大きいほど誤差が大きくなり、また測 定寸る鉄筋の径や周辺の鉄筋間隔も正確さに影響を与えることが知

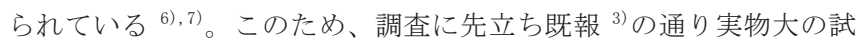
験体を用いた実験により補正式を求め、測定值から実際のかぶり厚 さを推定した。外装仕上げ材の厚さは、実際の仕上げ材厚さを実測 した結果より、上述の補正した值からタイル張り仕上げ面では $10 \mathrm{~mm}$ を、吹付けタイルおよびリシン吹付け仕上げ面では補正した值その ものを分析用のかぶり厚さとした。

かぶり厚さ調査を行った結果、 1 調查部材面当りの鉄筋本数の平 均, 最大および最小は、それぞれ柱では $15,24,12$ 本、壁では 13 , 19,10 本、梁側面では 23, 36, 14 本、梁下面は 24, 30, 7 本、スラ ブ下面は 52, 100, 14 本となっている。

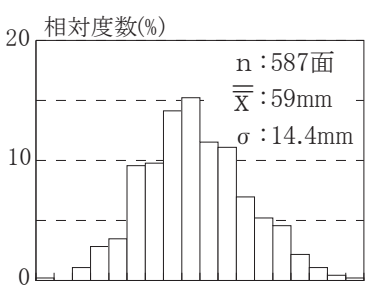

$$
\text { 平均值の分布(柱) }
$$

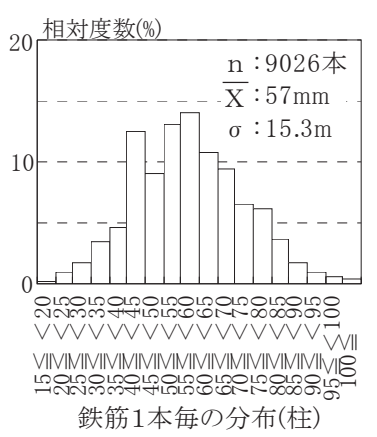

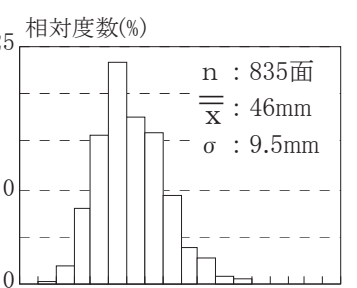

平均值の分布(壁)

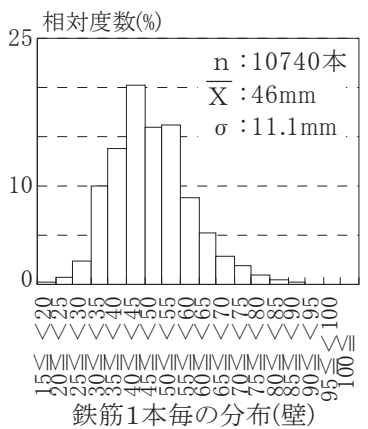

表 1 調査建物の規模および調査部材面数

\begin{tabular}{|c|c|c|c|c|c|c|c|c|}
\hline \multirow{2}{*}{$\begin{array}{l}\text { 建物 } \\
\text { 番号 }\end{array}$} & \multirow[b]{2}{*}{ 建物階数 } & \multirow{2}{*}{$\begin{array}{l}\text { 延床 } \\
\text { 面積 } \\
\left(\mathrm{m}^{2}\right) \\
\end{array}$} & \multirow[b]{2}{*}{ 竣工年 } & \multicolumn{5}{|c|}{ 調査部材面数 } \\
\hline & & & & 柱 & 壁 & $\begin{array}{l}\text { 大梁 } \\
\text { 側面 } \\
\end{array}$ & $\begin{array}{l}\text { 大梁 } \\
\text { 下面 }\end{array}$ & $\begin{array}{c}\text { スラブ } \\
\text { 下面 }\end{array}$ \\
\hline 1 & 7階建 & 8,399 & 2003年 & 29 & 90 & 30 & - & 15 \\
\hline 2 & 7階建 & 4,435 & 2003年 & 47 & 26 & 37 & 28 & 14 \\
\hline 3 & 7階建 & 3,328 & 2003年 & 12 & 30 & 11 & - & 6 \\
\hline 4 & 5階建 & 3,879 & 2003年 & 27 & 28 & 18 & 18 & 4 \\
\hline 5 & 5階建 & 3,826 & 2003年 & 30 & 32 & 18 & 18 & 4 \\
\hline 6 & 7階建 & 3,476 & 2003年 & 12 & 24 & 11 & - & 6 \\
\hline 7 & 10階建 & 6,585 & 2004年 & 50 & 90 & 30 & - & 15 \\
\hline 8 & 10階建 & 8,686 & 2004年 & 61 & 114 & 38 & - & 19 \\
\hline 9 & 11階建 & 7,086 & 2005年 & 44 & 60 & 38 & 35 & 15 \\
\hline 10 & 11階建 & 10,178 & 2005年 & 65 & 35 & 48 & 49 & 15 \\
\hline 11 & 11階建 & 7,855 & 2005年 & 54 & 60 & 44 & 30 & 15 \\
\hline 12 & 11階建 & 6,856 & 2005年 & 34 & 60 & 36 & 29 & 15 \\
\hline 13 & 10階建 & 6,680 & 2006年 & 24 & 33 & 20 & 24 & 10 \\
\hline 14 & 7階建 & 3,286 & 2006年 & 12 & 24 & 12 & - & 6 \\
\hline 15 & 5階建 & 2,840 & 2006年 & 10 & 12 & 7 & 8 & 2 \\
\hline 16 & 5階建 & 3,827 & 2006年 & 15 & 24 & 14 & 14 & 4 \\
\hline 17 & 7階建 & 3,256 & 2006年 & 16 & 36 & 14 & 9 & 3 \\
\hline 18 & 10階建 & 6,971 & 2006年 & 45 & 57 & 36 & 31 & 15 \\
\hline & 合 & 計 & & 587 & 835 & 462 & 293 & 183 \\
\hline
\end{tabular}

\section{4. 分析結果および考察}

\section{1 部材種別のかぶり厚さの分布}

各部材種別毎に、部材測定面毎のかぶり厚さ平均值の分布 (以下、 「平均值の分布」という) および鉄筋 1 本毎のかぶり厚さの分布(以下 「鉄筋 1 本毎の分布」という)について、それぞれの平均值と標準偏差 を表 2 に示す。平均值の差は 0〜 $2 \mathrm{~mm}$ 、標準偏差は「平均值の分布」の 方が僅かに小さくなる傾向があり $0.1 〜 2.2 \mathrm{~mm}$ の差があるものの、大 きな違いは見られない。各部材種別について、「平均值の分布」と「鉄 筋 1 本毎の分布」のヒストグラムを図 1 に示す。

表 2 平均值の分布および鉄筋 1 本毎の分布

\begin{tabular}{|c|c|c|c|c|c|c|c|c|c|c|}
\hline & \multicolumn{10}{|c|}{ 平均值および標準偏差 $\sigma(\mathrm{mm})$} \\
\hline & \multicolumn{2}{|c|}{ 柱 } & \multicolumn{2}{|c|}{ 壁 } & \multicolumn{2}{|c|}{ 梁側面 } & \multicolumn{2}{|c|}{ 梁下面 } & \multicolumn{2}{|c|}{ スラブ下面 } \\
\hline & 平均值 & $\sigma$ & 平均值 & $\sigma$ & 平均値 & $\sigma$ & 平均値 & $\sigma$ & 平均値 & $\sigma$ \\
\hline 平均值の分布 & 59 & 14.4 & 46 & 9.5 & 66 & 18.8 & 67 & 13.9 & 46 & 7.1 \\
\hline $\begin{array}{r}\text { 鉄筋1本毎 } \\
\text { の分布 }\end{array}$ & 57 & 15.3 & 46 & 11.1 & 65 & 19.0 & 67 & 16.1 & 48 & 7.0 \\
\hline
\end{tabular}

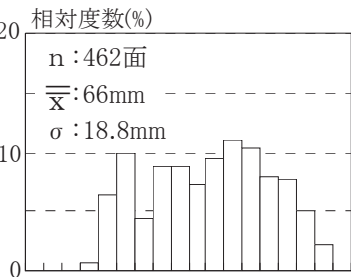

平均の分布(梁側面)

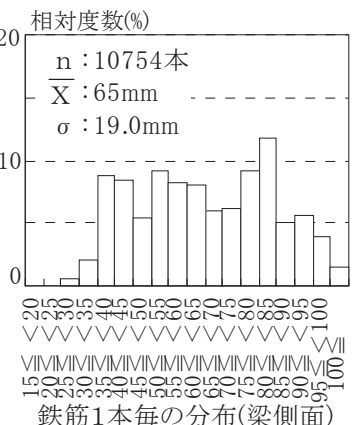

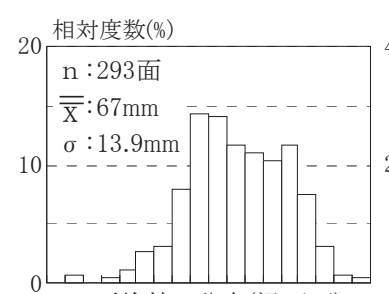

平均值の分布(梁下面)

$$
20 \begin{array}{|c|}
\text { 相対度数 }(\%) \\
\frac{\mathrm{n}: 7148 \text { 本 }}{\mathrm{X}: 67 \mathrm{~mm}} \\
\sigma: 16.1 \mathrm{~mm}
\end{array}
$$

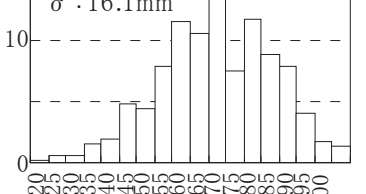

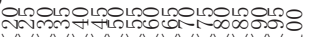

WWVVVWVWVVVW

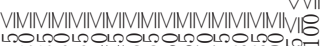

鉄筋 1 本毎の分布(梁下面)

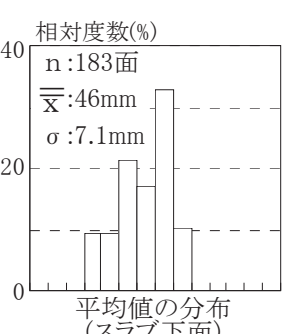

スフプ面 相対度数 $(\%)$ \begin{tabular}{l}
40 \begin{tabular}{l|l|l}
\hline $\mathrm{n}: 9436$ 本 & \\
\hline $\mathrm{X}: 48 \mathrm{~mm}$ & $\ldots$ \\
$\sigma$ & $: 7.0 \mathrm{~mm}$ \\
\hline
\end{tabular} \\
\hline
\end{tabular}

図 1 「平均值の分布」と「鉄筋 1 本毎の分布」 
「平均值の分布」は「鉄筋 1 本毎の分布」に対して、山の中央がやや高 くなり裾が低くなる傾向が見られるものの、分布の形状、分布の幅 ともに顕著な違いは見られない。

\section{2 測定面毎の平均値の分布}

(1) 柱

柱のかぶり厚さは、設計かぶり厚さが外部 $50 \mathrm{~mm}$ 内部 $40 \mathrm{~mm}$ に対し て、施工段階では帯筋の加工寸法を決めるためのかぶり厚さを外 部・内部とも $50 \mathrm{~mm}$ としている。一方躯体施工図によると、かぶり厚 さを測定した面には、タイルの割付や他部材との取合い等施工計画 上の理由による $15 \mathrm{~mm} \sim 57 \mathrm{~mm}$ の打増しが記載されている部材が多く あり、さらにその測定面の反対側面に 20〜 $57 \mathrm{~mm}$ の打増しがあるもの も含まれている。しかし、実際の施工では打増し寸法に応じた大き さのスペーサは使用されておらず、かぶり厚さ $50 \mathrm{~mm}$ 用のスペーサが 使われている。この打増しがかぶり厚さの分布に及ぼす影響は、既 報 ${ }^{4), 5)}$ の通りであり、部材内偏差および部材間偏差が大きくなり、 ばらつきが大きくなるという傾向がある。

これらの測定面および反対側面の打増し寸法の組合せのうち、測 定面数が 10 以上のものについて、「平均值の分布」および「鉄筋 1 本 毎の分布」それぞれの平均值と標準偏差を表 3 に示す。また、測定面 数が 14 以下と比較的少ないものを除き、測定面と反対側面の打増し 寸法の合計と標準偏差の関係を図 2 に示寸。測定面の打増し寸法 0 、 反対側面の打増し寸法 0 (以下、打増し 0-0 という。以下同様) のと き、「平均值の分布」、「鉄筋 1 本毎の分布」それぞれの標準偏差およ びその差は小さく、打増しがある場合にはそれぞれの標準偏差およ びその差が大きくなる傾向が見られる。しかしながら、標準偏差の 差は、いずれの場合も「平均值の分布」の方が $1 \sim 3 \mathrm{~mm}$ 程度小さくなる だけである。この理由は既報 ${ }^{4)}$, 5) の通りであり、打増しの影響によ り部材内偏差および「平均值の分布」の標準偏差である部材間偏差が 大きくなる傾向があるものの、部材内偏差は部材間偏差に比べ值が 小さく、また打増しの影響による変化も小さいことから、部材間偏 差の影響が大きく現れることによる。次に、打増し 0-0 および標準 偏差の差が最も大きい打増し 20-0 のヒストグラムを図 3 に示す。 「平均值の分布」は「鉄筋 1 本毎の分布」に比べ山の中央が高く裾が低 くなる傾向が見られるものの、 $5 \mathrm{~mm}$ 毎の区間による分布の幅は打増 し 20-0 の左側裾が 2 区間、その他の裾は 1 区間と僅かに狭くなる程 度である。以上のことは、かぶり厚さの分布の特性として、かぶり 厚さの小さい鉄筋は建物全体に散らばっているのではなく、かぶり 厚さの平均值の小さい部材面に集中して存在しているという特徵を 表しているといえる。

表 3 のうち、打増し 0-0, 20-0 の「平均值の分布」について、X軸 にかぶり厚さ測定值、Y軸に期待值を表した正規確率プロットを図 4 に示す。なお、測定值に対する期待值は、市販のソフトウェア ${ }^{8)}$ を用いて求めた。いずれの場合も、プロットが対角線上をほぼ直線 的に並んでいることから、これらの分布は正規分布に近似している と考えられる。また、表 3 のそれぞれの「平均值の分布」について、 上記のソフトウェアを用いコルモゴロフ・スミルノフ検定 (以下、K・ $\mathrm{S}$ 検定という)による正規性の仮説検定を行った。その結果はいずれ も有意確率が 0.05 以上となり、「平均值の分布」が正規分布に従うと いう仮説は亲却されないと判定されている。
表 3 平均值の分布および鉄筋 1 本毎の分布(柱)

\begin{tabular}{|c|c|c|c|c|c|c|c|}
\hline \multirow{2}{*}{\begin{tabular}{|c} 
測定面の \\
打増し \\
$(\mathrm{mm})$ \\
\end{tabular}} & \multirow{2}{*}{\begin{tabular}{|c} 
反対面の \\
打増L \\
$(\mathrm{mm})$
\end{tabular}} & \multicolumn{3}{|c|}{ 平均値の分布 } & \multicolumn{3}{|c|}{ 鉄筋 1 本毎の分布 } \\
\hline & & $\begin{array}{l}\text { 測定面 } \\
\text { 数(面) }\end{array}$ & $\begin{array}{c}\text { 平均值 } \\
\text { (mm) }\end{array}$ & \begin{tabular}{|c|} 
標準偏差 \\
$(\mathrm{mm})$
\end{tabular} & $\begin{array}{l}\text { 鉄筋数 } \\
\text { (本) }\end{array}$ & $\begin{array}{c}\text { 平均値 } \\
\text { (mm) }\end{array}$ & \begin{tabular}{|c|} 
標準偏差 \\
$(\mathrm{mm})$
\end{tabular} \\
\hline \multirow[t]{2}{*}{ 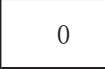 } & 0 & 48 & 51 & 9.3 & 786 & 51 & 10.3 \\
\hline & 20 & 11 & 62 & 18.3 & 153 & 61 & 18.3 \\
\hline 20 & 0 & 71 & 61 & 8.9 & 1249 & 61 & 12.1 \\
\hline \multirow{2}{*}{25} & 0 & 288 & 55 & 13.1 & 4624 & 53 & 14.7 \\
\hline & 25 & 47 & 68 & 15.4 & 635 & 65 & 16.6 \\
\hline 27 & 47 & 14 & 55 & 15.9 & 230 & 56 & 17.0 \\
\hline 37 & 0 & 44 & 66 & 14.8 & 544 & 63 & 15.4 \\
\hline 47 & 40 & 14 & 68 & 11.7 & 183 & 64 & 12.2 \\
\hline \multicolumn{2}{|c|}{ 上記の合計 } & 537 & - & - & 8404 & - & - \\
\hline 柱三 & 全体 & 587 & 59 & 14.4 & 9026 & 57 & 15.3 \\
\hline
\end{tabular}

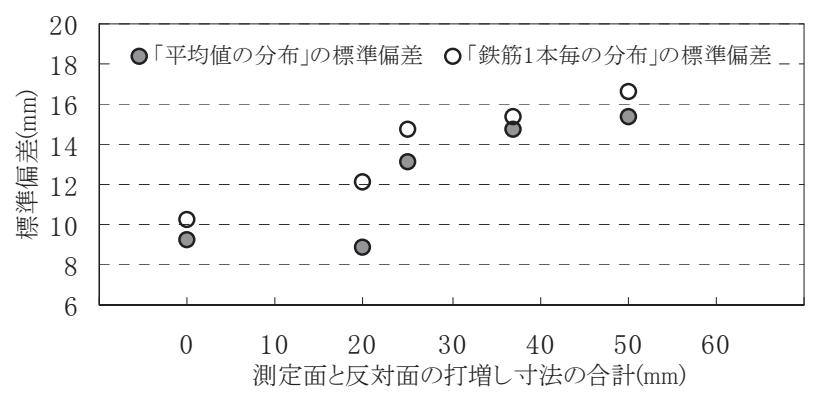

図 2 打増し寸法と標準偏差の関係(柱)

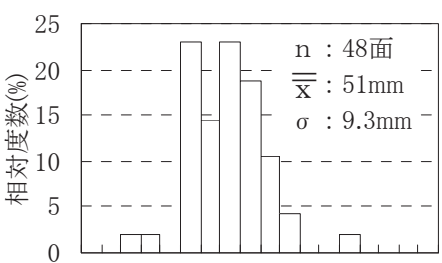

平均値の分布(打増し $0-0$ )

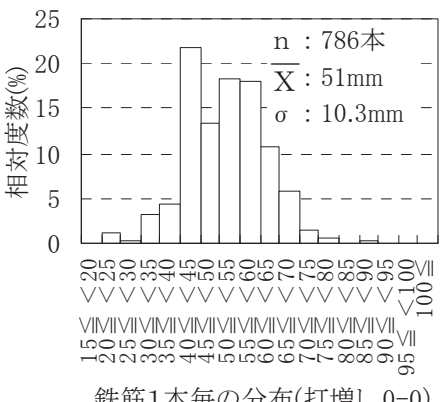

図 3 平均值の分布と鉄筋 1 本毎の分布 (柱)
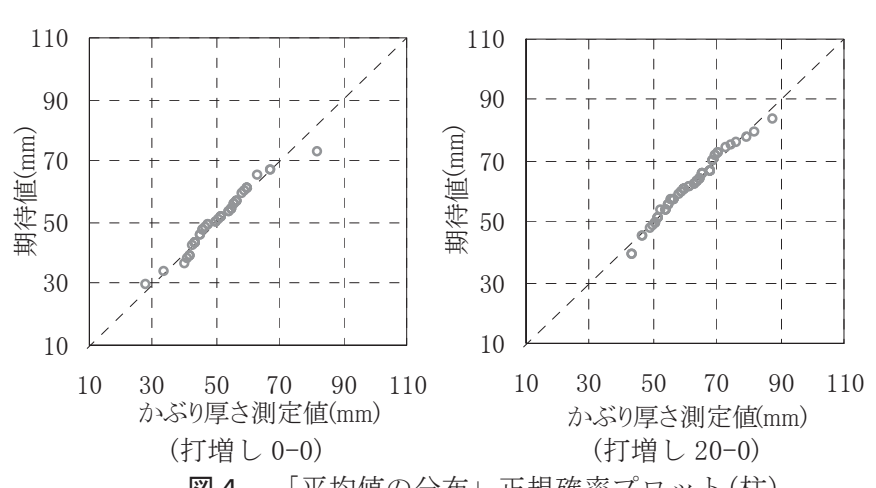

図 4 「平均值の分布」正規確率プロット (柱)

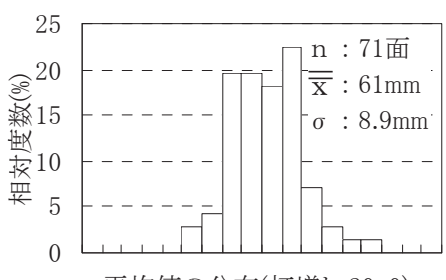

平均値の分布(打増し 20-0)

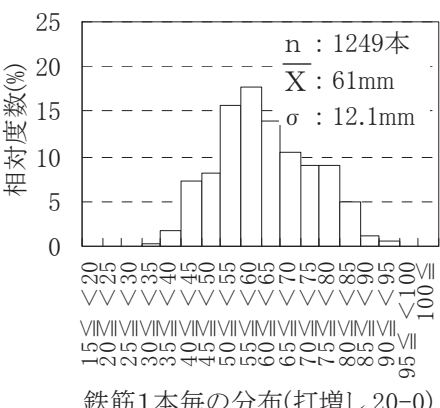

鉄筋1本毎の分布(打増し 20-0) 
(2) 壁

壁のかぶり厚さ測定面は、屋外側と内部階段室等の屋内側があり、 設計かぶり厚さは前述の通りそれぞれ $50 \mathrm{~mm}$ および $40 \mathrm{~mm}$ である。躯 体施工図によると、壁のかぶり厚さ測定面には施工計画上の理由に よる $10 \mathrm{~mm} \sim 57 \mathrm{~mm}$ の打増しが記載されている部材が多くあり、さらに その測定面の反対側面にも打増しの記載があるものが含まれている。 設計かぶり厚さ、測定面および反対側面の打増し寸法の組合せの うち、測定面数 10 以上について「平均值の分布」および「鉄筋 1 本毎 の分布」それぞれの平均值と標準偏差を表 4 に示す。なお、表 4 のう ち測定面の打増し $0 ， 10$ は設計かぶり厚さ $40 \mathrm{~mm} 、 15,25$ は同 $50 \mathrm{~mm}$ である。また、測定面数が 15 以下と比較的少ないものを除き、測定 面と反対側面の打増し寸法の合計と標準偏差の関係を図 5 に示寸。 「平均值の分布」、「鉄筋 1 本毎の分布」それぞれの標準偏差は、柱の 場合と同様な傾向を示しており、その差は 1 2mm 程度と僅かである。 次に測定面数の比較的多い、打増し $0-0$ および $25-0$ について、「平 均值の分布」および「鉄筋 1 本毎の分布」それぞれのヒストグラムを 図 6 に示寸。それぞれの分布は柱の場合と同様に、「平均值の分布」 の幅の方が 1 ないし 2 区間ほど僅かに狭くなっている。

「平均值の分布」について、打増し 0-0 および 25-0 の正規確率プロ ットを図 7 に示す。どちらもプロットが対角線上をほぼ直線的に並 んでおり、正規分布に近似していると考えられる。また、表 4 の組 合せ全てについて $K \cdot S$ 検定による正規性の仮説検定を行うと、打増 し 0-0 以外については、「平均值の分布」が正規分布に従うという仮 説は棄却されないと判定されている。

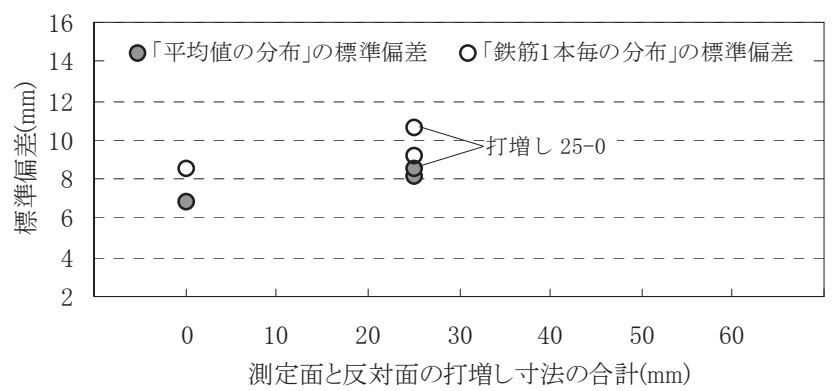

図 5 打増し寸法と標準偏差の関係(壁)

(3) 梁側面

梁側面のかぶり厚さは、柱と同様にあばら筋の加工寸法を決める ためのかぶり厚さを、外部・内部とも $50 \mathrm{~mm}$ としている。一方構造図 や躯体施工図によると、かぶり厚さを測定した面には、柱主筋と大 梁主筋との交差の影響による 25〜35mm の割増し(主筋、あばら筋と も呼び名を鉄筋外径とする)があり、さらにタイルの割付け等施工計 画上の理由による 15〜25mm の打増しが記載されている部材が多く ある。

これらの割増し寸法と打増し寸法の組合せのうち、測定面数 10 以上について「平均值の分布」および「鉄筋 1 本毎の分布」それぞれの 平均值と標準偏差を表 5 に示す。また、測定面数が 17 以下と比較的 少ないものを除き、割増し寸法・打増し寸法の合計と標準偏差の関 係を図 8 に示寸。「平均值の分布」および「鉄筋 1 本毎の分布」それぞ れの標準偏差は、柱, 壁の場合と同様な傾向を示している。次に、 割増し 0 打増し 0 (以下、0-0 という。以下同様) および標準偏差の差
表 4 平均値の分布および鉄筋 1 本毎の分布 (壁)

\begin{tabular}{|c|c|c|c|c|c|c|c|}
\hline \multirow{2}{*}{$\begin{array}{c}\text { 測定面 } \sigma \\
\text { 打増L } \\
(\mathrm{mm})\end{array}$} & \multirow{2}{*}{$\begin{array}{c}\text { 反対面の } \\
\text { 打増し } \\
(\mathrm{mm}) \\
\end{array}$} & \multicolumn{3}{|c|}{ 平均值の分布 } & \multicolumn{3}{|c|}{ 鉄筋1本毎の分布 } \\
\hline & & $\begin{array}{l}\text { 測定面 } \\
\text { 数(面) }\end{array}$ & $\begin{array}{c}\begin{array}{c}\text { 平均值 } \\
(\mathrm{mm})\end{array} \\
\end{array}$ & $\begin{array}{c}\text { 標準偏差 } \\
(\mathrm{mm})\end{array}$ & $\begin{array}{l}\text { 鉄筋数 } \\
\text { (本) }\end{array}$ & $\begin{array}{c}\text { 平均值 } \\
(\mathrm{mm})\end{array}$ & $\begin{array}{c}\text { 標準偏戾 } \\
(\mathrm{mm})\end{array}$ \\
\hline \multirow{3}{*}{0} & 0 & 291 & 40 & 6.8 & 3377 & 40 & 8.5 \\
\hline & 9 & 15 & 42 & 3.0 & 135 & 42 & 5.4 \\
\hline & 25 & 52 & 46 & 8.1 & 557 & 46 & 9.2 \\
\hline \multirow{2}{*}{10} & 15 & 12 & 58 & 5.1 & 136 & 57 & 6.5 \\
\hline & 57 & 12 & 65 & 11.7 & 119 & 66 & 12.6 \\
\hline 15 & \multirow{2}{*}{0} & 12 & 50 & 6.7 & 149 & 49 & 8.0 \\
\hline 25 & & 435 & 50 & 8.6 & 6195 & 50 & 10.7 \\
\hline \multicolumn{2}{|c|}{ 上記の合計 } & 829 & - & - & 10668 & - & - \\
\hline \multicolumn{2}{|c|}{ 壁全体 } & 835 & 46 & 9.5 & 10740 & 46 & 11.1 \\
\hline
\end{tabular}

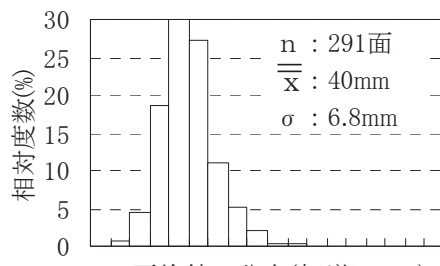

平均值の分布(打増し $0-0$ )

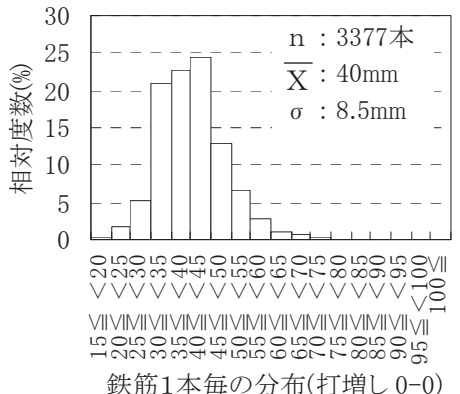

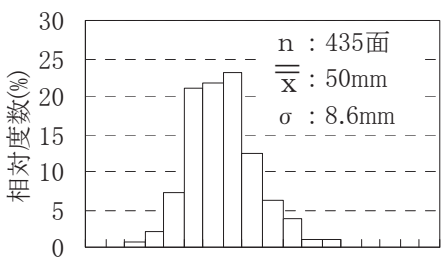

平均值の分布(打増し 25-0)

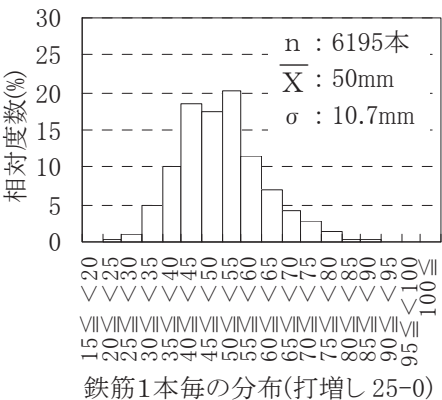

鉄筋1本毎の分布(打増し 25-0)
図 6 平均值の分布と鉄筋 1 本毎の分布 (壁)
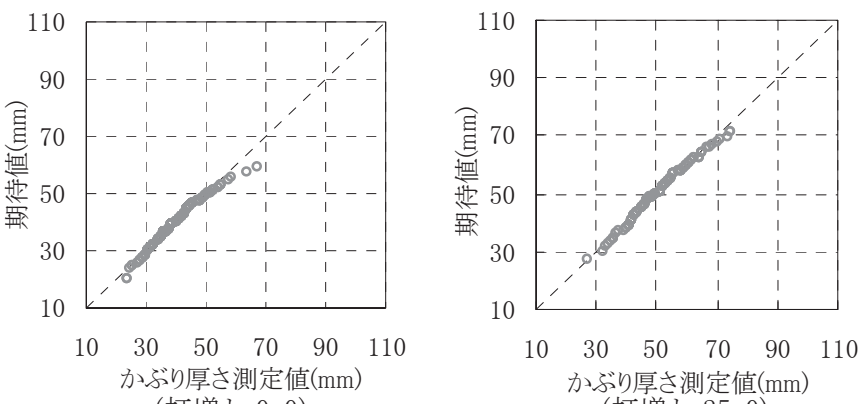

(打増し $0-0$ )

図 7 「平均值の分布」正規確率プロット(壁)

表 5 平均值の分布および鉄筋 1 本毎の分布 (梁側面)

\begin{tabular}{|c|c|r|c|r|r|r|r|}
\hline \multicolumn{2}{|c|}{ 測定面 } & \multicolumn{3}{|c|}{ 平均値の分布 } & \multicolumn{2}{c|}{ 鉄筋1本毎の分布 } \\
\hline $\begin{array}{c}\text { 割増し } \\
(\mathrm{mm})\end{array}$ & $\begin{array}{c}\text { 打増し } \\
(\mathrm{mm})\end{array}$ & $\begin{array}{c}\text { 測定面 } \\
\text { 数(面) }\end{array}$ & $\begin{array}{c}\text { 平均值 } \\
(\mathrm{mm})\end{array}$ & $\begin{array}{c}\text { 標準偏差 } \\
(\mathrm{mm})\end{array}$ & $\begin{array}{c}\text { 鉄筋数 } \\
(\text { 本 })\end{array}$ & $\begin{array}{c}\text { 平均值 } \\
(\mathrm{mm})\end{array}$ & $\begin{array}{c}\text { 標準偏差 } \\
(\mathrm{mm})\end{array}$ \\
\hline \multirow{2}{*}{0} & 0 & 81 & 44 & 7.7 & 1786 & 43 & 8.2 \\
\cline { 2 - 9 } & 20 & 31 & 56 & 10.8 & 1169 & 55 & 13.1 \\
\hline 28 & 25 & 42 & 69 & 10.6 & 774 & 67 & 13.8 \\
\hline 29 & 25 & 101 & 78 & 13.4 & 2676 & 78 & 14.9 \\
\hline 32 & 25 & 115 & 71 & 12.0 & 2270 & 72 & 15.2 \\
\hline 35 & 25 & 17 & 75 & 11.8 & 265 & 75 & 14.3 \\
\hline \multicolumn{2}{|c|}{ 上記の合計 } & 387 & - & - & 8940 & - & - \\
\hline \multicolumn{2}{|c|}{ 大梁側面全体 } & 462 & 66 & 18.8 & 10754 & 65 & 19.0 \\
\hline
\end{tabular}


が比較的大きい 28-25について、「平均值の分布」および「鉄筋 1 本毎 の分布」それぞれのヒストグラムを図 9 に示す。前述の柱, 壁の場合 と同様に、 $5 \mathrm{~mm}$ 毎の区間による分布の幅は、「平均值の分布」の方が 両裾において 1 ないし 2 区間ほど僅かに狭くなっている。

0-0 および 28-25 の「平均值の分布」について、正規確率プロット を図 10 に示す。0-0 の両端付近を除けば、プロットは対角線上を ほぼ直線的に並んでいる。また、表 5 の組合せ全てについて $\mathrm{K} \cdot \mathrm{S}$ 検 定による正規性の仮説検定を行うと、0-0 および 29-25 以外にいて は、「平均值の分布」が正規分布に従うという仮説は棄却されないと 判定されている。
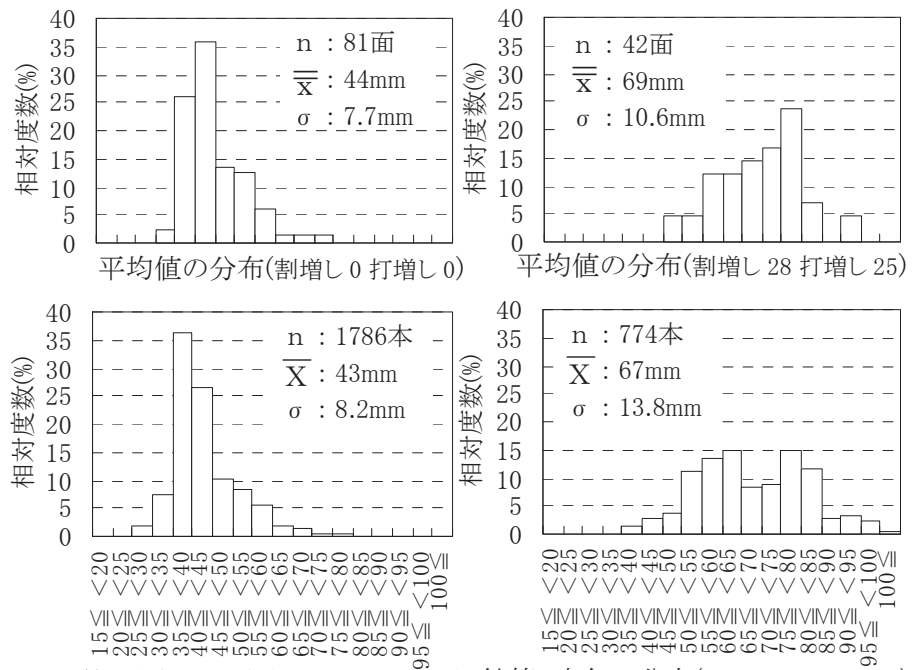

鉄筋 1 本毎の分布(割増し 0 打増し 0) 鉄筋 1 本毎の分布(割増し 28 打増し 25）

図 9 平均值の分布と鉄筋 1 本毎の分布 (梁側面)

\section{（4）梁下面およびスラブ下面}

梁下面の測定面は全て屋外側で、躯体施工図によると $10 、 20 、 30 \mathrm{~mm}$ の打増しが記載されている部材が含まれており、反対側面となる梁 上面に打増しはない。また、スラブ下面では、かぶり厚さの保持方 法が調査建物 18 棟のうち 5 棟では設計かぶり厚さ寸法 $40 \mathrm{~mm}$ のスペ 一サで下端主筋を直接受ける方法がとられ、その他の 13 棟では設計 かぶり厚さ寸法 $40 \mathrm{~mm}$ のスペーサの上にさらに受け筋 D10 を配置し、 その上に下端主筋をのせるという方法がとられている。

梁下面は測定面の打増し寸法毎のうち測定面数が 10 以上につい て、またスラブ下面はかぶり厚さ保持方法別に、「平均值の分布」お よび「鉄筋 1 本毎の分布」それぞれの平均值と標準偏差を表 6 および 表 7 に示す。梁下面についてそれぞれの標準偏差の差は、 $2 \sim 3 \mathrm{~mm}$ 程度と前述の各部材と同程度であり、スラブ下面については標準偏 差の差はほとんど見られない。

「平均值の分布」の正規確率プロットは、梁下面、スラブ下面とも 前述の各部材と同様な傾向を示しており、K·S 検定による正規性の 仮説検定では、梁下面の打増し 10 のみが、正規性に従うという仮説 が棄却されないと判定されている。

\section{3 測定面の平均値と部材内偏差の関係}

各部材種別について、測定面のかぶり厚さ平均值とその測定面の かぶり厚さの部材内偏差の関係を図 11〜図 15 に示寸。各部材とも、

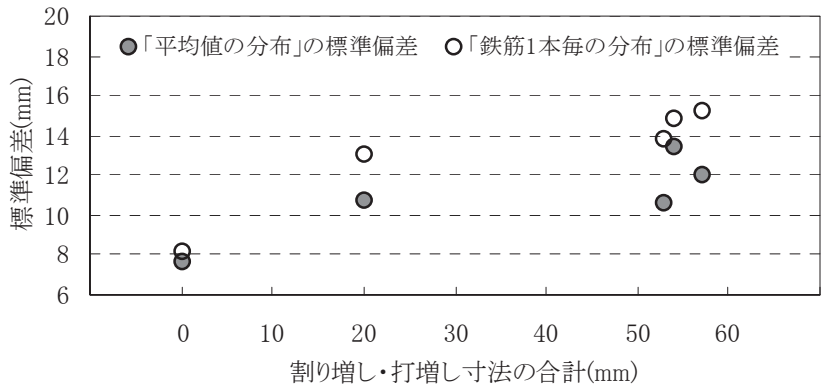

図 8 割増し·打増し寸法と標準偏差の関係(梁側面)
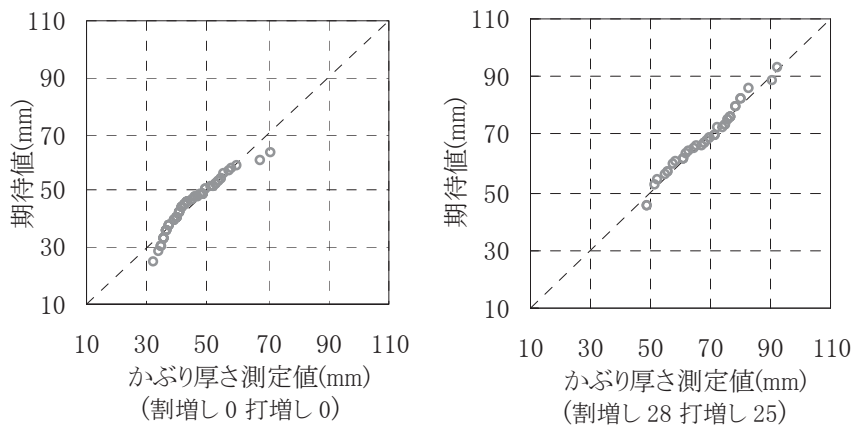

図 10 「平均値の分布」正規確率プロット(梁側面)

表 6 平均值の分布および鉄筋 1 本毎の分布 (梁下面)

\begin{tabular}{|c|c|c|c|c|c|c|c|}
\hline \multirow{2}{*}{$\begin{array}{c}\text { 測定面の } \\
\text { 打増し } \\
(\mathrm{mm})\end{array}$} & \multirow{2}{*}{\begin{tabular}{|c}
$\begin{array}{l}\text { 反対面の } \\
\text { 打増し } \\
(\mathrm{mm})\end{array}$ \\
\end{tabular}} & \multicolumn{3}{|c|}{ 平均値の分布 } & \multicolumn{3}{|c|}{ 鉄筋1本毎の分布 } \\
\hline & & $\begin{array}{l}\text { 測定面 } \\
\text { 数(面) }\end{array}$ & $\begin{array}{c}\text { 平均値 } \\
\text { (mm) }\end{array}$ & $\begin{array}{c}\text { 標準偏差 } \\
\text { (mm) }\end{array}$ & $\begin{array}{l}\text { 鉄筋数 } \\
\text { (本) }\end{array}$ & $\begin{array}{c}\text { 平均値 } \\
(\mathrm{mm})\end{array}$ & \begin{tabular}{|c} 
標準偏差差 \\
$(\mathrm{mm})$
\end{tabular} \\
\hline 0 & \multirow{3}{*}{0} & 41 & 56 & 7.9 & 987 & 55 & 10.4 \\
\hline 10 & & 36 & 48 & 9.6 & 1017 & 47 & 12.5 \\
\hline 30 & & 207 & 73 & 10.9 & 4958 & 73 & 12.8 \\
\hline 梁下 & 全体 & 293 & 67 & 13.9 & 7148 & 67 & 16.1 \\
\hline
\end{tabular}

表 7 平均值の分布および鉄筋 1 本毎の分布 (スラブ下面)

\begin{tabular}{|c|c|c|c|c|c|c|}
\hline \multirow{2}{*}{$\begin{array}{l}\text { スラブ下端筋の } \\
\text { がぶり厚さ保持 } \\
\text { 方法 } \\
\end{array}$} & \multicolumn{3}{|c|}{ 平均值の分布 } & \multicolumn{3}{|c|}{ 鉄筋 1 本毎の分布 } \\
\hline & $\begin{array}{l}\text { 測定面 } \\
\text { 数(面) }\end{array}$ & $\begin{array}{l}\begin{array}{c}\text { 平均値 } \\
(\mathrm{mm})\end{array} \\
\end{array}$ & $\begin{array}{c}\text { 標準偏差 } \\
(\mathrm{mm})\end{array}$ & $\begin{array}{l}\text { 鉄笳数 } \\
\text { (本) }\end{array}$ & $\begin{array}{l}\text { 平均值 } \\
(\mathrm{mm})\end{array}$ & $\begin{array}{c}\text { 標準偏差 } \\
(\mathrm{mm})\end{array}$ \\
\hline $\begin{array}{l}\text { 40mmスペーサ } \\
\text { を設置 }\end{array}$ & 70 & 43 & 6.7 & 2002 & 43 & 7.1 \\
\hline 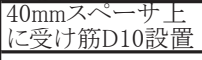 & 113 & 48 & 6.7 & 7434 & 50 & 6.3 \\
\hline 全体 & 183 & 46 & 7.1 & 9436 & 48 & 7.0 \\
\hline
\end{tabular}
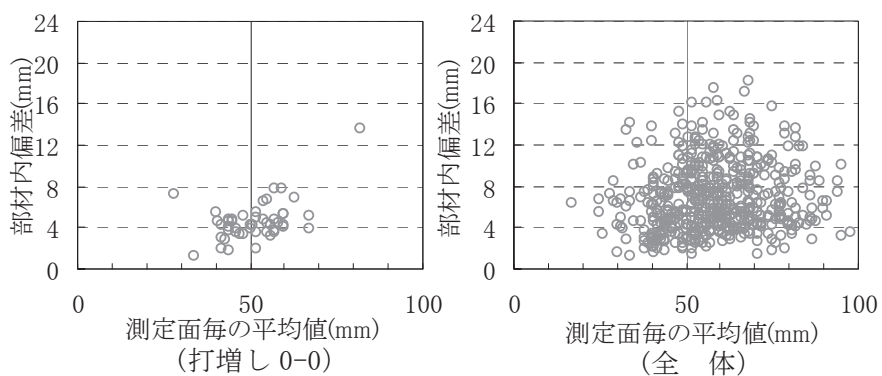

図 11 測定面の平均值と部材内偏差の関係 (柱) 
割増しや打増しがないものおよび割増しや打増しを含む全ての測定 面について示した。一部傾向の異なるデータも見られるが、各部材 種別において、測定面の平均值が小さい場合は部材内偏差の大きい ものが少なく、測定面の平均值が大きくなると部材内偏差の大きい ものが多くなる傾向が見られる。この理由として既報 ${ }^{4)}$,5) で報告し た様に、割増しや打増しの影響によって部材内偏差が大きくなる傾 向のあることが影響していると思われる。また、割増しや打増しの ない部材面についても同様な傾向が見られることから、既報 ${ }^{3)}$ で報 告した様にかぶり厚さが大きくなると非破壊試験による誤差が大き くなることの他に、かぶり厚さの平均值が設計かぶり厚さ近辺の場 合は、かぶり厚さの施工精度が良く部材内偏差が小さくなっている ことも考えられる。

次に、測定面のかぶり厚さ平均値を $5 \mathrm{~mm}$ の区間毎に分けて部材内 偏差の平均值を求めたものを、設計かぶり厚さ $50 \mathrm{~mm}$ の柱, 梁側面, および梁下面を表 8 に、設計かぶり厚さ $40 \mathrm{~mm}$ の壁，スラブ下面を表 9 に示す。なお、各区間における部材内偏差のデータ数が 3 以下の ものは除外した。

表 8 かぶり厚さ平均値の範囲毎の部材内偏差の平均值 $(\mathrm{mm})$ (柱, 梁側面, 梁下面：設計かぶり厚さ $50 \mathrm{~mm}$ )

\begin{tabular}{|c|l|c|c|c|c|c|c|}
\hline \multirow{2}{*}{ 部材種別 } & \multirow{2}{*}{\begin{tabular}{c} 
打増し等の区分 \\
\cline { 3 - 8 }
\end{tabular}} & $\begin{array}{r}35 \leqq \overline{\mathrm{x}} \\
<40\end{array}$ & $\begin{array}{c}40 \leqq \overline{\mathrm{x}} \\
<45\end{array}$ & $\begin{array}{c}45 \leqq \overline{\mathrm{x}} \\
<50\end{array}$ & $\begin{array}{c}50 \leqq \overline{\mathrm{x}} \\
<55\end{array}$ & $\begin{array}{c}55 \leqq \overline{\mathrm{x}} \\
<60\end{array}$ & $\begin{array}{c}60 \leqq \overline{\mathrm{x}} \\
<65\end{array}$ \\
\hline \multirow{2}{*}{ 柱 } & 打増し0-0 & - & 3.7 & 4.1 & 4.4 & 4.9 & 5.2 \\
\cline { 2 - 9 } & 柱全体 & 6.0 & 5.1 & 6.5 & 7.0 & 7.5 & 7.1 \\
\hline \multirow{2}{*}{ 梁側面 } & 割増し0打増し0 & 2.9 & 4.5 & 6.7 & 6.0 & 8.4 & - \\
\cline { 2 - 9 } & 梁側面全体 & 3.3 & 4.8 & 6.6 & 6.4 & 8.1 & 8.7 \\
\hline \multirow{2}{*}{ 梁下面 } & 打堌し0-0 & - & 5.1 & - & 6.6 & 6.3 & 8.3 \\
\cline { 2 - 9 } & 梁下面全体 & 5.5 & 7.2 & 6.6 & 6.5 & 7.5 & 7.5 \\
\hline
\end{tabular}

表 9 かぶり厚さ平均值の範囲毎の部材内偏差の平均值 $(\mathrm{mm})$ (壁, スラブ下面 : 設計かぶり厚さ $40 \mathrm{~mm}$ )

\begin{tabular}{|c|c|c|c|c|c|c|c|}
\hline \multirow[b]{2}{*}{ 部材種別 } & \multirow[b]{2}{*}{ 打増し等の区分 } & \multicolumn{6}{|c|}{ 測定面の平均値 $\bar{x}$ の範囲 (mm) } \\
\hline & & \begin{tabular}{rl|}
25 & $\leqq \bar{x}$ \\
& $<30$ \\
\end{tabular} & $\begin{aligned} 30 \leqq \overline{\mathrm{x}} \\
<35\end{aligned}$ & $\begin{aligned} 35 \leqq \bar{x} \\
<40\end{aligned}$ & $\begin{aligned} 40 \leqq \overline{\mathrm{x}} \\
<45\end{aligned}$ & $\begin{aligned} 45 & \leqq \bar{x} \\
& <50\end{aligned}$ & $\begin{aligned} 50 \leqq \overline{\mathrm{x}} \\
<55\end{aligned}$ \\
\hline \multirow{2}{*}{ 壁 } & 打増し $0-0$ & 4.9 & 3.7 & 4.5 & 4.6 & 5.0 & 6.8 \\
\hline & 壁全体 & 4.9 & 3.8 & 4.4 & 4.5 & 4.8 & 5.5 \\
\hline \multirow{2}{*}{ スラブ下面 } & $40 \mathrm{~mm}$ スペーサ & - & 2.5 & 3.7 & 3.0 & 4.0 & 2.8 \\
\hline & スラブ下面全体 & - & 2.8 & 4.1 & 3.1 & 4.1 & 3.1 \\
\hline
\end{tabular}

各部材種別毎の割増しや打増しのない部材面について、かぶり厚 さ平均值の範囲毎に部材内偏差の平均值を図 16 に示す。鉛直部材の 柱、壁については、かぶり厚さの平均值が小さくなると部材内偏差 も小さくなる傾向が見られ、設計かぶり厚さ〜設計かぶり厚さ一 $10 \mathrm{~mm}$ (以下、最小かぶり厚さという)の範囲において、部材内偏差が 最も小さくなっている。これは、前述のように非破壊試験の誤差の 影響の他、かぶり厚さの平均值が設計かぶり厚さ〜最小かぶり厚さ 近辺のものは、かぶり厚さの施工精度が比較的良いことが影響して いることも考えられる。水平部材の梁側面、梁下面については、全 体的に部材内偏差がやや大きめとなり、一部で部材内偏差の大きさ が僅かに逆転する部分もあるが、全体の傾向としては柱、壁と同様 であると考えられる。スラブ下面については同様な傾向は見られず、 いずれの範囲においても部材内偏差が小さい值となっている。これ は、スラブ下面がスペーサの設置により、かぶり厚さの施工精度を 比較的確保し易いことを表しているともいえる。

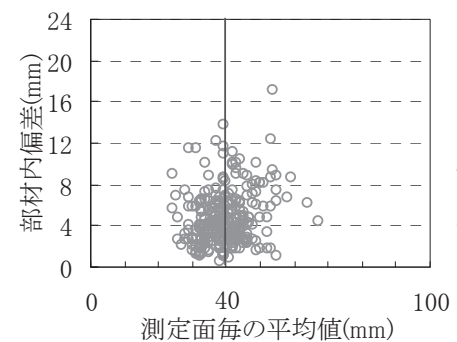

(打増し $0-0$ )

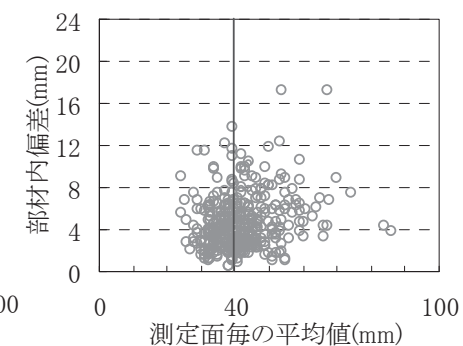

(全 体)

図 12 測定面の平均值と部材内偏差の関係 （設計かぶり厚さ $40 \mathrm{~mm}$ の壁）
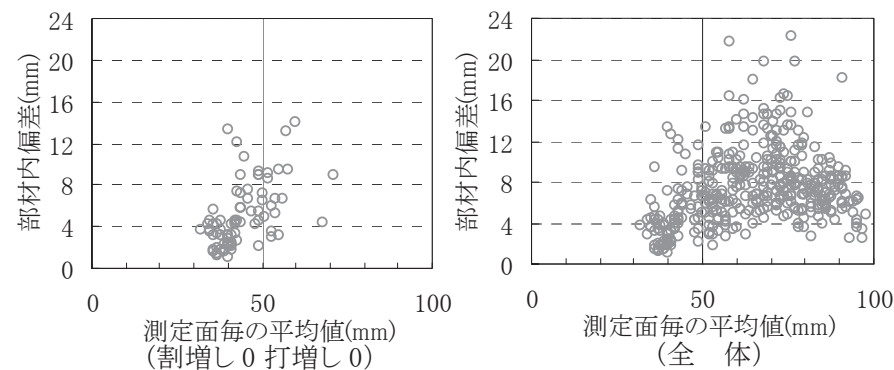

図 13 測定面の平均値と部材内偏差の関係(梁側面)
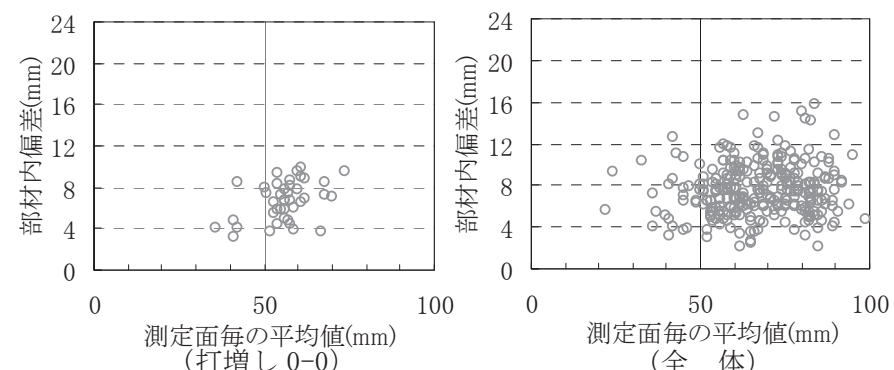

図 14 測定面の平均值と部材内偏差の関係 (梁下面)
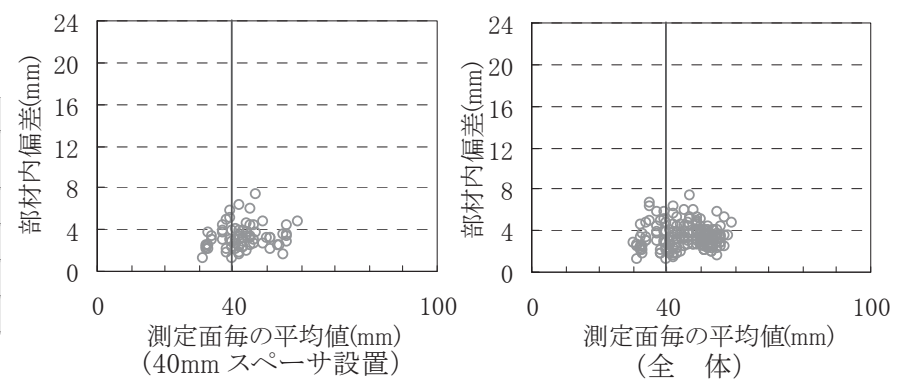

図 15 測定面の平均値と部材内偏差の関係 (スラブ下面)

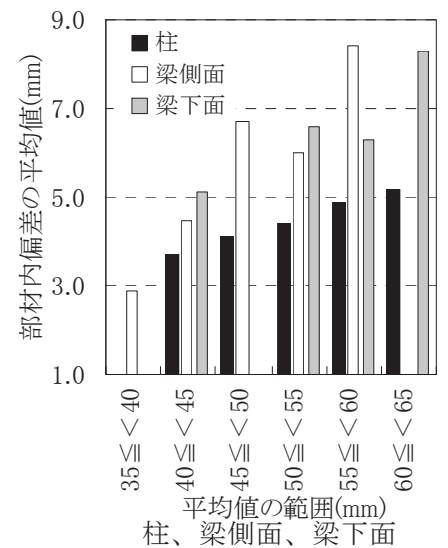

柱、梁側面、梁下面

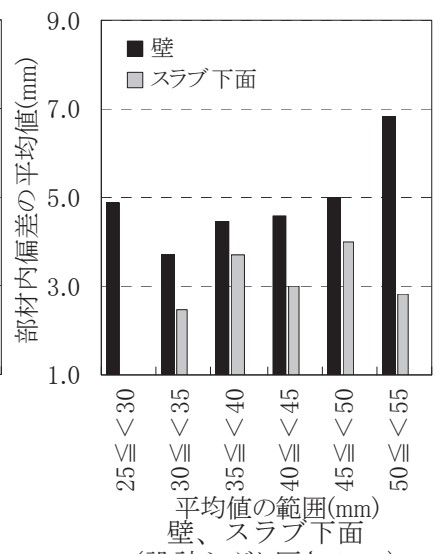

(設計かぶり厚さ $40 \mathrm{~mm}$ )

図 16 平均値の範囲毎の部材内偏差の平均值 (割増しや打増しのない部材) 
これらのことから、割増しや打増しの影響を受けていない部材面 の場合、かぶり厚さの平均值が設計かぶり厚さ〜最小かぶり厚さ近 辺の場合は、部内偏差の平均值は $5 \mathrm{~mm}$ 程度以下と考えて良いと思わ れる。

\section{5. まとめ}

実際の鉄筋コンクリート造建物 18 棟を対象とした非破壊試験に よるかぶり厚さ調查結果をもとに、柱、壁、梁側面、梁下面および スラブ下面について、部材測定面毎のかぶり厚さ平均值の分布、お よびかぶり厚さの平均值と部材内偏差の関係を分析した結果は次の 通りである。

（1）各部材種別毎に割増し寸法や打増し寸法毎に分けて、測定面毎 のかぶり厚さの平均值の分布と鉄筋 1 本毎のかぶり厚さの分布に ついて、標準偏差および $5 \mathrm{~mm}$ 区間のヒストグラムの分布を比較し た場合、「平均值の分布」は「鉄筋 1 本毎の分布」に比べ僅かに分 布の幅が狭くなる程度である。これは、かぶり厚さの分布の特性 として、かぶり厚さの小さい鉄筋は建物全体に散らばっているの ではなく、かぶり厚さの平均值の小さい部材面に集中して存在し ているという特徴を表している。

（2）各部材種別の測定面毎のかぶり厚さ平均值の分布は、割増しや 打増し寸法毎に分けた場合、それぞれ正規分布に近似していると して扱ってよいと考えられる。

（3）測定面のかぶり厚さ平均值とかぶり厚さの部材内偏差の関係は、 測定面の平均值が小さい場合は部材内偏差が大きいものは少なく、 測定面の平均值が大きくなると部材内偏差の大きいものが多くな る傾向がある。これは、割増しや打増しの影響および非破壊試験 による誤差の影響などが考えられる。

（4）割増しや打増しのない部材面について、測定面のかぶり厚さの 平均值と部材内偏差の関係をみると、柱，壁，梁側面，梁下面で は平均值が小さくなると部材内偏差が小さくなる傾向があり、ス ラブ下面については全体的に部材内偏差が小さくなっている。ま た、各部材とも測定面の平均值が設計かぶり厚さ〜最小かぶり厚 さ近辺のときに部材内偏差が最も小さくなり、このときの部材内 偏差は $5 \mathrm{~mm}$ 程度以下と考えられる。

\section{参考文献}

1）嵩英雄，和泉意登志，友沢史紀，福士勲：経年 $\mathrm{R} \mathrm{C}$ 構造物におけるコン クリートの中性化と鉄筋の腐食, 第 6 回コンクリート工学年次講演会論文 集，pp. 181 184，1984

2）桝田佳寛，友沢史紀，矢島義麿：実際の鉄筋コンクリート造建築物にお ける鉄筋のかぶり厚さの実態, 第 7 回コンクリート工学年次講演会論文集, pp45〜48，1985

3）西村進，桝田佳寛，松崎育弘，園部泰寿：実際の鉄筋コンクリート造建 築物におけるかぶり厚さの分布に関する調査と分析, 日本建築学会構造系 論文集，第 649 号，pp. 491〜 497，2010.3

4）西村進，桝田佳寬，松崎育弘，園部泰寿：鉄筋コンクリート造建築物の 柱・梁側面におけるかぶり厚さの分布に及ぼす割増しや打増しの影響, 日 本建築学会構造系論文集，第 657 号，pp. 1941～1946，2010.11

5）西村進，桝田佳宽，松崎育弘，園部泰寿：鉄筋コンクリート造建築物の 壁・梁・スラブにおけるかぶり厚さの分布に及ぼす打増しや施工方法の影 響，日本建築学会構造系論文集，第 658 号，pp. 2079～2085，2010. 12

6） 日本コンクリート工学協会：コンクリート診断技術“'07 基礎編，2007.1

7）濱崎仁，川西泰一郎，桝田佳寛，鹿毛忠継：実構造物におけるかぶり厚 さの測定誤差およびその補正方法に関する検討，コンクリート工学年次論 文集, Vol. 30, No. 2, pp. 799 804，2008.7

8）社会情報サービス，エクセル統計 2008

\section{注}

注 1) 日本建築学会, 鉄筋コンクリート造配筋指針・同解説 2003, 付録 C 用語 によれば、鉄筋の納まりから部材の最小寸法に加算される割増しの幅を 「割増し幅」、またコンクリート部材や鉄筋の納まりからあるいは建築意匠 の関係から、構造上の必要断面にコンクリートを付加することを「打増し」 と記されている。その用語を参考とした。

（2010年10月10日原稿受理，2011年 2 月22日採用決定） 